\title{
Student Perspectives on the Challenges Faced During the Transition to High School
}

\author{
Elis A. Kristo \\ Newton North High School, 457 Walnut Street, Newtonville, MA 02460, U.S.A.; gentikristo@gmail.com
}

\begin{abstract}
The transition from middle school to high school is a pivotal time in the life of a student and has the potential to be quite stressful. The goal of this study was to evaluate the concerns of ninth-grade students when entering high school. An anonymous web-based survey regarding their experience $s$ with the transition from middle school to high school was distributed to twenty-one ninth-grade student from a high school in Boston, MA in April 2019. A total of 21 of 24 surveys were completed ( $87.5 \%$ response rate). The most significant student concern related to their high school transition was the ability to manage their time, followed by increased academic expectations, greater amount of homework, adjusting to new classmates, making new friends, and adjusting to new teachers. For improving transition to high school, students proposed more personalized support in the early phase of the transition to high school and better communication between parents and school counselors in order to identify and address student concerns in a timely fashion. Therefore, teachers, counselors, and parents should work together in identifying strategies to help students entering high school.

KEYWORDS: Behavioral and Social Sciences; Clinical and Developmental Psychology; High School Transition; High School Counselors; High School Teachers.
\end{abstract}

\section{- Introduction}

The transition from middle school to high school has the potential to be stressful. High school is a time when many ninth graders find themselves lost in an unfamiliar, less personal environment, struggling to keep up with the demanding coursework that was not as present in middle school. ${ }^{1}$ Research has shown that students who experience a positive transition and successful freshman year, are more likely to have a successful overall high school experience. ${ }^{2}$ On the other hand, students that do not have a successful transition into high school are more likely to become discouraged and eventually drop out of school. ${ }^{3}$ Indeed, studies suggest that approximately one-third of the recent high school dropouts never were promoted beyond ninth grade. ${ }^{4}$ The goal of this study was to evaluate the concerns of ninth-grade classmates during their transition from middle school to high school.

\section{Methods}

An anonymous web-based survey regarding high school freshmen's experience with the transition from middle school to high school (Table 1) was distributed to twenty-four ninthgrade student from a high school in Boston, MA in April 2019. Students were in a different classroom than that of the author and the survey was approved by the dean of the freshmen class. The survey was completed, and the information was analyzed to determine the concerns raised by the students entering high school.

\section{Results and Discussion}

A total of 21 of 24 surveys were completed (87.5\% response rate) by both female $[42.9 \%(9 / 21)]$ and male $[57.1 \%(12 / 21)]$ participants.
Table 3: Survey questions.

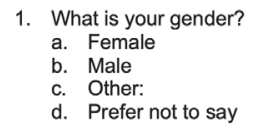

2. What middle school did you graduate from?

3. What are the most important challenges that you faced during the transition to high school? a. Adjusting to new classmates

b. Adjusting to new teacher

c. Academic expectation

d. Academic expectations
e. Amount of homework

f. Ability to manage my time

g. Other:

4. What suggestions (if any) do you have for improving the transition to high school?

The most significant student concern related to their high school transition was the ability to manage their time (31\%), followed by increased academic expectations ( $24 \%)$, greater amount of homework (17\%), adjusting to new classmates (10

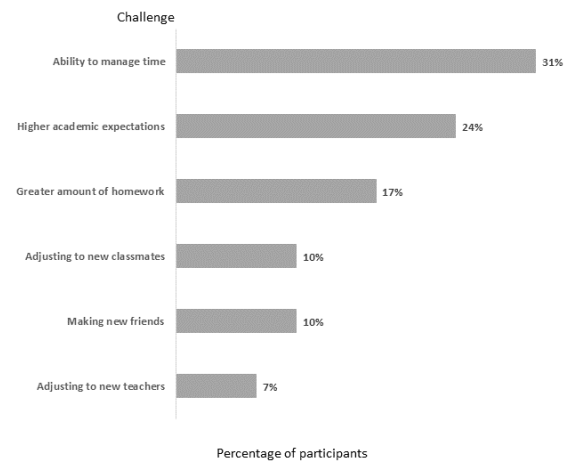

Figure 1: : Challange faced by students during their transition to high school. 
When asked about suggestions for improving the transition to high school, students proposed more personalized support in the early phase of the transition to high school and better communication between parents and school counselors in order to identify and address student concerns in a timely fashion. The responses were comparable when stratified by gender and the name of middle school.

The results of the study show that the most significant challenge experienced by students during their transition to high school is managing their time while trying to adapt to increasing academic expectations and workload. This is in line with studies showing that academic concerns are the most prominent during the transition to high school, ${ }^{5}$ followed, similar to our study, by social concerns (making new friends and fitting in), ${ }^{6}$ and procedural concerns (becoming familiar with the new teachers, new school infrastructure, and the new schedule). ${ }^{7,8}$

The ninth-grade students participating in the survey suggested more personalized support during the onboarding to high school and improved communication between parents and school counselors in order to identify and address student concerns in a timely fashion.

The crucial role of school counselors in supporting students during their transition to high school is well recognized. ${ }^{9}$ The American School Counselor Association (ASCA) has developed best practices guidelines that school counselors follow to help students overcome the challenges of high school transition. ${ }^{10}$ School counselors could further improve the middle-to-high school transition experience of their students by performing a more in-depth intake assessment of their students in order to identify students that would benefit from an earlier support. ${ }^{9}$ Furthermore, in order to provide a more comprehensive understanding of the issues that students face when entering high school, close communication between counselors, teachers, and parents is very important.

Parent involvement is essential for a successful transition to high school. Indeed, studies show that when parents work closely with teachers and remain involved in the education of their high-school children, ninth graders have a more successful experience. ${ }^{6}$ Importantly, the students participating in this study recognize the importance of parent involvement for their transition to high school. They would welcome better communication between their parents and counselors, both early, during the onboarding process, and throughout the ninth grade.

The present study has some limitations. First, the small sample size could limit the ability to generalize the findings. Surveying a larger group of high school ninth grade students from multiple institutions would be an important next step in generalizing and validating the findings of the study. Second, although the response rate was very high $(87.5 \%)$, meaningful differences between students who answered the questionnaire, and the non-respondents cannot be excluded. Third, a ranking scale rather than the "best answer" question format in would have better assessed the perspectives of the students on challenges faced during their transition to high school. Fourth, a pre- and post- transition survey would have better assessed transition challenges and provided insights on the transition expectations of middle school students.

Even with these limitations, the findings provide meaningful insights into the challenges faced by students during their transition to high school.

\section{Conclusion}

The transition to high school is a critical period for students. The results of the survey show that improved transition support is needed for the incoming high school freshmen. Teachers, counselors, and parents should work together in identifying strategies to help students entering high schoool.

\section{- Acknowledgements}

The work described here was not funded by any source. The author thanks his class dean, Michelle Stauss, for her support with this project.

\section{References}

1. Smith, R. Bridging the Transition from Middle School to High School. Counselor Education Master's Theses. 2013, 140. http://digitalcommons.brockport.edu/edc_theses/ 140 (accessed Oct 3, 2020).

2. McIntosh, J.; White, S. Building for Freshman Success:

High Schools Working as Professional Learning Communities. American Secondary Education. 2006, 34 (2), 40-49.

3. Cooney, S.; Bottoms, G. From the Middle Level to High school: A Big Step Toward Success. Principal Leadership. 2003, Atlanta: Southern Regional Education Board. https://files. eric.ed.gov/fulltext/ED479785.pdf (accessed Nov 8, 2020).

4. Neild, RC. (2009). Falling Off Track During the Transition to High School: What We Know and What Can Be Done. Future of Children. 2009, 19, 53-76.

5. Cushman, K. Help Us Make the Ninth Grade Transition. Educational Leadership. 2006, 63 (7), 47-52.

6. Akos, P.; Galassi, PJ. (2004). Middle and High School Transitions as Viewed by Students, Parents, and Teachers. Professional School Counseling. 2004, 74, 212-221.

7. Mizelle, N. Moving Out of Middle School. Educational Leadership. 2005, 62 (7), 56-60.

8. Letrello, TM.; Miles, DD. The Transition from Middle School to High School. Clearing House. 2003, 76 (4), 212-214.

9. Dimmitt, C.; Carey J. Using the ASCA National Model to Facilitate School Transitions. Professional School

Counseling. 2007, 10 (3), 227-232

10. Bowers, J.; Hatch, PA. The ASCA National Model. A Framework for School Counseling Programs. Second Edition. Alexandria, VA: American Counseling Association, 2002

\section{- Author}

Elis A. Kristo is a junior student at the Newton North High School in Newton, Massachusetts. As one of the elected leaders of his high school student council for three years in a row, he is passionate about working with others to improve the high school experience for all students, as well as increase their impact in the community. Elis is a thoughtful individual who works with passion, dedication, and respect. As a child of immigrants from Albania, Elis has a deep appreciation of the importance of the community in supporting students reach their potential. 